\title{
Coupling between the thermohaline, chemical and biological fields during summer 2006 in the northeast continental shelf of the Gulf of Cádiz (SW Iberian Peninsula)
}

\author{
ELEONORA ANFUSO ${ }^{1}$, ROCIO PONCE ${ }^{1}$, CARMEN GONZALEZ CASTRO $^{2}$ \\ and JESÚS M. FORJA ${ }^{1}$ \\ ${ }^{1}$ Departamento de Química Física, Facultad de Ciencias del Mar y Ambientales, Universidad de Cádiz, Campus Río San \\ Pedro, s/n, 11510 Puerto Real, Cádiz. E-mail: eleonora.anfuso@uca.es \\ ${ }_{2}^{2}$ Departamento de Oceanografía, Instituto de Investigaciones Marinas, CSIC, c/ Eduardo Cabello 6, 36208 Vigo, \\ Pontevedra, Spain.
}

\begin{abstract}
SUMMARY: The coupling between the thermohaline, chemical and biological variables on the northeast continental shelf of the Gulf of Cádiz was determined during the Emigas I survey in summer 2006. Samples were collected to chemically characterize the different water types and to analyze the chlorophyll $a$ distribution. Four different water masses were identified: North Atlantic Central Water (NACW), Surface Atlantic Water (SAW), considered a modification of NACW, and South and North Surface Waters. The highest nutrient levels were found in subsurface NACW, while surface waters were almost nutrientdepleted except in the Guadalquivir region. The isopycnal level of $26.3 \mathrm{~kg} \mathrm{~m}^{-3}$ marked the limit between nutrient-rich NACW and nutrient-poor surface waters. At the offshore stations, the subsurface cholorophyll $a$ maximum was located at the depth of nitracline and associated with the $26.3 \mathrm{~kg} \mathrm{~m}^{-3}$ isopycnal level rather than with the pycnocline depth. At the inshore stations, chlorophyll $a$ maxima were observed at the bottom, except for the surface maximum in the River Guadalquivir region.
\end{abstract}

Keywords: nutrients, chlorophyll a, nitracline, River Guadalquivir, Gulf of Cádiz.

RESUMEN: ACOPLAMIENTO DE LAS VARIABLES TERMOHALINAS, QUímicas Y BIOLÓGICAS DURANTE EL VERANO 2006 EN

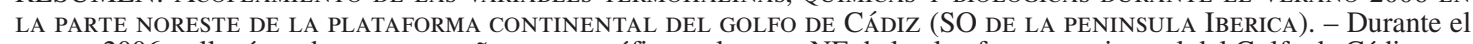
verano 2006 se llevó a cabo una campaña oceanográfica en la parte NE de la plataforma continental del Golfo de Cádiz para determinar el acoplamiento de las variables termohalinas, químicas y biológicas. En cada estación se tomaron muestras para la caracterización química de las diferentes masas de agua y el análisis de la distribución de clorofila- $a$. Se diferenciaron cuatro tipos distintos de masas de agua: North Atlantic Central Water (NACW); Surface Atlantic Water (SAW), que es una modificación de la primera y las aguas superficiales del Norte y del Sur. Las concentraciones más elevadas de nutrientes se encontraron asociadas con las aguas profundas (NACW); en cambio las aguas superficiales estaban prácticamente agotadas en nutrientes, con excepción de las estaciones próximas a la desembocadura del Río Guadalquivir. El límite entre NACW rica en nutrientes y las aguas con bajas concentraciones de nutrientes fue establecido en el nivel isopícnico de $26.3 \mathrm{~kg} \mathrm{~m}^{-3}$. Para las estaciones exteriores, el máximo subsuperficial de clorofila- $a$ no se encontró en la posición de la picnoclina sino en la de la nitraclina, asociado al nivel isopícnico de $26.3 \mathrm{~kg} \mathrm{~m}^{-3}$. Para las estaciones interiores, el máximo de clorofila se localizó cerca del fondo, con excepción de la región del Río Guadalquivir, donde se observó un máximo superficial.

Palabras clave: nutrientes, clorofila- $a$, nitraclina, rio Guadalquivir, golfo de Cádiz.

\section{INTRODUCTION}

From a geochemical and biological point of view, coastal areas are very active sites where major exchang- es with the open ocean take place (Gattuso et al., 1998). About $25 \%$ of total oceanic primary production occurs on the continental shelves (Wollast, 2002), associated with continental nutrient input (Wollast, 1993) and up- 
welling processes (Wollast, 1998). The Gulf of Cádiz is a basin that connects the North Atlantic Ocean and the Mediterranean Sea through the Strait of Gibraltar. The flux of Atlantic waters affects the oceanographic characteristics of surface waters in the Gulf of Cádiz and plays an important role in the regulation of circulation in the Mediterranean Sea (Navarro and Ruiz, 2006). In the basin three different structures were identified (Stevenson 1977): the upwelling Portuguese zone off Cape San Vicente (Fiuza et al., 1982; Fiuza, 1983), the thermal front southeastward of Cape Santa Maria (Huelva front), correlated with the wind regime (Fiuza et al., 1982; Fiuza, 1983; Folkard et al., 1997), and the anticyclonic circulation of the Tarifa Eddy at Cape Trafalgar (Stevenson, 1977) (Fig. 1). In general, the circulation in the Gulf of Cádiz is predominantly anticyclonic with short-term variations during summer (Garcia et al., 2002; Criado-Aldeanueva et al., 2006b) and likely to switch to cyclonic in winter (Garcia-Lafuente and Ruiz, 2007). Different water masses were found in the Gulf of Cádiz (Gascard and Richez, 1985; Criado-Aldeanuvea et al., 2006a). At surface, two different water types were described: Surface Atlantic Water (SAW) and Surface Water (SW). SAW is located in the central part of the gulf in the anticyclonic meander while SW, warmer and fresher than the latter, is observed over the continental shelf. At intermediate depth, the basin is filled by North Atlantic Central Water (NACW) lying between 100 and $700 \mathrm{~m}$ (Folkard et al., 1997) and characterized by a linear relationship in the TS diagram. The NACW upwells on the south and west coast of Portugal, off Cape St. Vincent and Cape St. Maria (Fiuza, 1983; Folkard et al., 1997; Revals and Barton, 2002; Sanchez and Revals, 2003). Below a certain depth $(<700 \mathrm{~m})$ the basin is occupied by Mediterranean water (MW) identified by its high salinity ( $>36.1)$.

Previous studies have shown that the Gulf of Cádiz experiences strong oligotrophic conditions during summer, as surface nitrate levels were almost depleted for the entire region except the River Guadalquivir outflow (García et al., 2002; Huertas et al., 2005; Navarro et al., 2006; Navarro and Ruiz, 2006; Ruiz et al., 2006; Huertas et al., 2006). All these studies were devoted to analyzing the chlorophyll $a$ distribution in the Gulf of Cádiz and its relationship with the physical variables on a basin scale, , but no detailed survey of the continental shelf has been carried out yet. Furthermore, few studies have dealt with the chemical characterization of the water masses in the area and they mainly focus on horizontal distributions of nutrients in the upper $50 \mathrm{~m}$ (Prieto et al., 1999; García et al., 2002; Huertas et al., 2005; Ruiz et al., 2006; Huertas et al., 2006). Only Navarro et al. (2006) reported nutrient concentrations at $200 \mathrm{~m}$ depth and Garcia et al., (2002) at $100 \mathrm{~m}$ depth.

In this context, this paper aims to 1) chemically characterize the water types on the northeast continental shelf of the Gulf of Cádiz and 2) analyze the relationship between the thermohaline field and chemical and biological variables in the region during a summer situation.



FIG. 1. - Location map of the northeastern continental shelf of the Gulf of Cádiz located in the SW Iberian Peninsula. CSV, CSM and CT stand for Cape San Vicente, Cape Santa Maria and Cape Trafalgar. The grid indicates the sampling points for the Emigas I cruise, showing the reference transects analyzed in detail (transect F and B respectively). The isobar units are in metres.

\section{MATERIALS AND METHODS}

The study area was located on the northeastern shelf of the Gulf of Cádiz (SW Iberian Peninsula) (Fig. 1). The sampling stations selected covered an area from the Bay of Cádiz to the River Guadalquivir. The data were collected during the Emigas I oceanographic cruise, carried out from 17 to 29 June 2006 on board the R/V Mytilus. For this cruise a grid of 63 stations, shared in 9 transects, was sampled. At each station, continuous vertical profiles of temperature, salinity, pressure and fluorescence were obtained with a Seabird CTD probe coupled to a Seatech fluorometer and a Seabird 43 dissolved oxygen sensor. Photosynthetic available radiation (PAR) profiles were also measured using a Biospherical QSP 2000 sensor. Discrete water samples were collected at different depths $(0,20$ and the deepest one depending on the bathymetry of the area) in the water column for analysis of nutrients and chlorophyll $a(\mathrm{chl} a)$. Samples for nitrate, phosphate and silicate were filtered on board through $0.45 \mu \mathrm{m}$ Millipore filters, immediately frozen at $-20^{\circ} \mathrm{C}$ and analyzed in the laboratory. Nutrients were determined by segmented 

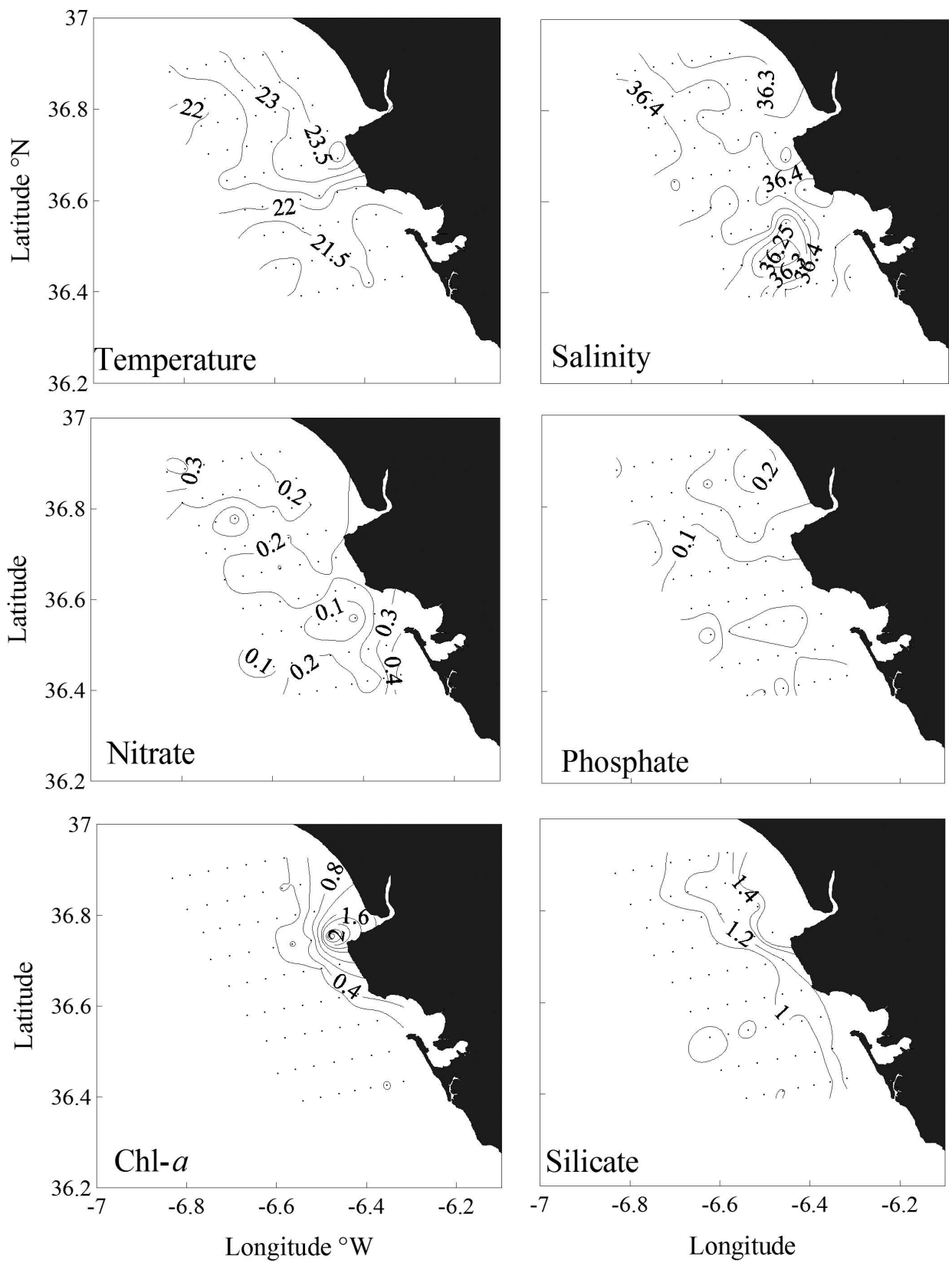

FIG. 2. - Horizontal distribution of sea surface temperature, salinity, nitrate, phosphate, chl $a$ and silicate in the Gulf of Cádiz in June 2006. $\mathrm{T}$ in ${ }^{\circ} \mathrm{C}$, chl $a$ in $\mathrm{mg} \mathrm{m}^{-3}$ and nutrients in $\mu \mathrm{M}$.

flow analysis with Alpkem autoanalyzers following Grasshoff et al. (1983). The analytical errors were \pm 0.05 $\mu \mathrm{M}$ for nitrate and silicate, and $\pm 0.01 \mu \mathrm{M}$ for phosphate. Samples for chl $a$ of about $500 \mathrm{~mL}$ were filtered on board using Millipore filters $(0.45 \mu \mathrm{m})$, frozen at $-20^{\circ} \mathrm{C}$ and then analyzed in the laboratory by fluorimetry after extraction with $90 \%$ acetone in the dark.

Nitracline depth was defined as the shallowest depth at which nitrate concentration was higher than $1 \mu \mathrm{M}$, as described by Moran et al. (2001). The interpolation method used for the analysis of the thermohaline, chemical and biological fields distribution was kriging.

\section{RESULTS}

\section{Thermohaline, chemical and chl $a$ horizontal distributions}

In Figure 2, the thermohaline, chemical and chl $a$ surface horizontal distributions are described. Sea surface temperature varied typically between $21^{\circ} \mathrm{C}$ and $24^{\circ} \mathrm{C}$. This temperature distribution was marked by a strong north-south gradient with the highest values close to the River Guadalquivir. South of $36.6^{\circ} \mathrm{N}$, temperature was lower than $22^{\circ} \mathrm{C}$, with almost no ocean-shelf gradient. Sea surface salinity values ranged between 36.20 and 

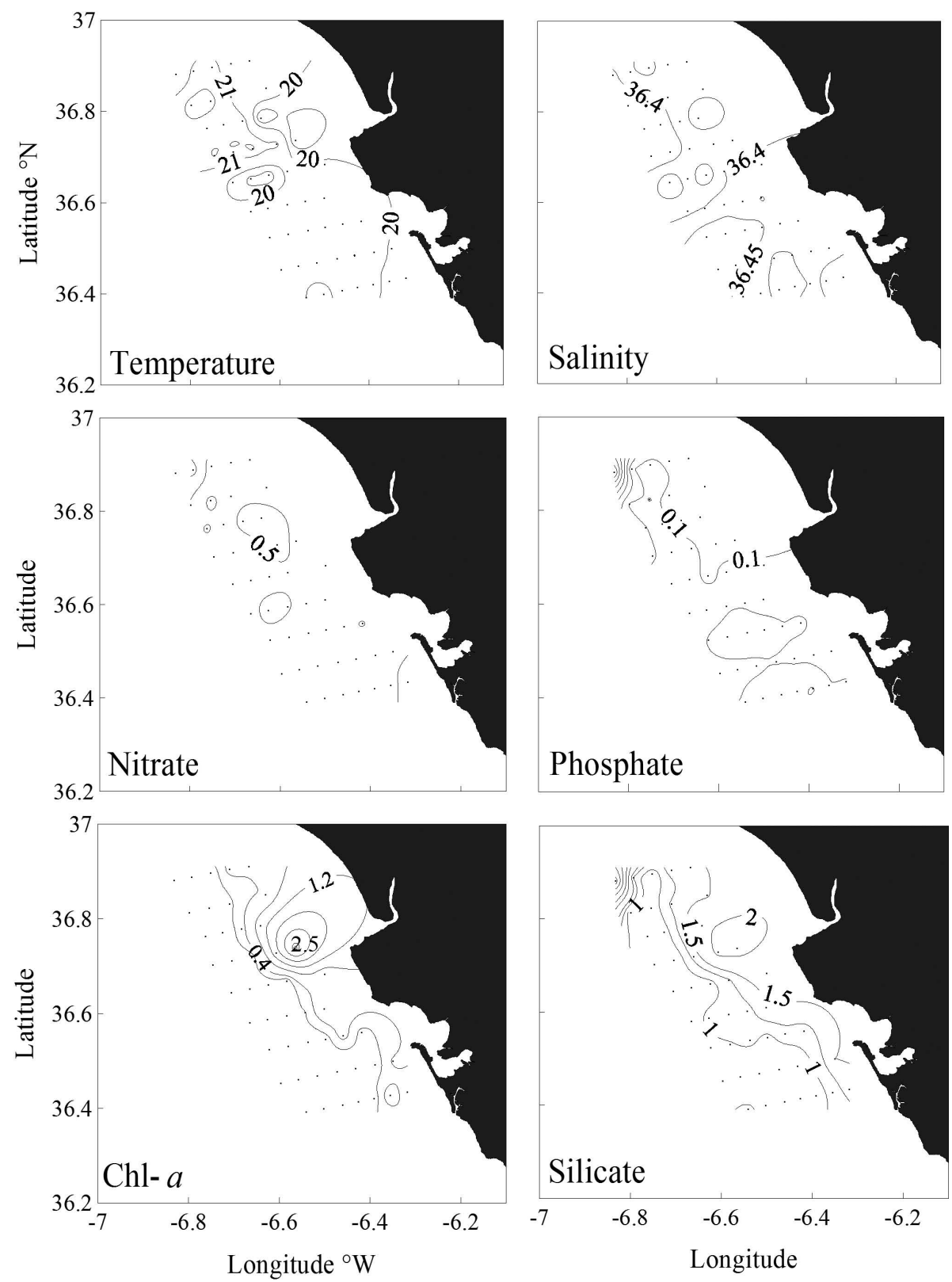

FIG. 3. - Horizontal distribution at $20 \mathrm{~m}$ depth of temperature, salinity, nitrate, phosphate, chl $a$ and silicate in the Gulf of Cádiz in June 2006. $\mathrm{T}$ in ${ }^{\circ} \mathrm{C}$, chl $a$ in $\mathrm{mg} \mathrm{m}^{-3}$ and nutrients in $\mu \mathrm{M}$.

36.45 (Fig. 2). Surface nitrate and phosphate concentrations were almost depleted for the entire study area. Nitrate concentrations only reached values higher than $0.4 \mu \mathrm{M}$ close to the mouth of the Bay of Cádiz, while the highest phosphate levels were observed in the north, close to the River Guadalquivir $(>0.1 \mu \mathrm{M})$. Surface silicate distribution was characterized by a coast-oceanward gradient with maximum values $(>1 \mu \mathrm{M})$ close to the River Guadalquivir. Chl $a$ surface values were low for the whole area except close to the River Guadalquivir, where levels as high as $2.6 \mathrm{mg} \mathrm{m}^{-3}$ were recorded.

The subsurface temperature distribution at $20 \mathrm{~m}$ depth was similar to the sea surface distribution (Fig. 3 ), with temperatures ranging between $19^{\circ} \mathrm{C}$ and $22^{\circ} \mathrm{C}$.
We observed a north-south zonation in the temperature and salinity distributions. The north part was characterized by lower salinity values and an inshore-offshore temperature gradient, with minimum temperature close to the River Guadalquivir. In contrast, the subsurface temperature south of $36.6^{\circ} \mathrm{N}$ was mainly homogenous $\left(20.6 \pm 0.7^{\circ} \mathrm{C}\right)$. At $20 \mathrm{~m}$ depth, nitrate and phosphate levels were still very low, with values not higher than 1 $\mu \mathrm{M}$ and $0.1 \mu \mathrm{M}$ for nitrate and phosphate, respectively. Silicate distribution resembled the surface distribution, with a clear ocean-coastwards gradient. Finally, chl $a$ concentrations at this depth were also higher close to the coast. The highest values were reached in the River Guadalquivir region (chl $a \sim 2.5 \mathrm{mg} \mathrm{m}^{-3}$ ) (Fig. 3). 



FIG. 4. - Vertical distribution of temperature, salinity, nitrate, phosphate, chl $a$ and silicate at transect F in the Gulf of Cádiz in June 2006 . T in ${ }^{\circ} \mathrm{C}$, chl $a$ in $\mathrm{mg} \mathrm{m}^{-3}$, and nutrients in $\mu \mathrm{M}$.

\section{Thermohaline, chemical and chl $a$ vertical distributions}

In order to analyze the vertical distribution of the variables in the study area, we selected two transects corresponding to the north and south part (Figs. 4 and 5 , respectively). The northern transect is located off the River Guadalquivir (transect F) and the south transect off the Bay of Cádiz (transect B) (Fig. 1). The maximum surface temperatures were recorded in the northern transect, causing a stronger stratification for this region compared with the south. For the northern transect, we observed a temperature variation of approximately $3.5^{\circ} \mathrm{C}$ in the upper $30 \mathrm{~m}$ (Fig. 4), compared with $2^{\circ} \mathrm{C}$ in the upper $30 \mathrm{~m}$ for the southern transect (Fig. 5). Below 30 m, the thermohaline properties were similar for the two transects. For the upper metres, the most striking feature in the salinity distributions was the lens of lower salinity in the southern transect, that it was as deep as $15 \mathrm{~m}$ (Fig. 5). In spite of this marked salinity minimum, the density distributions for the two transects were clearly controlled by temperature (distributions not shown). The nitrate dis- tribution for both transects showed that surface waters were completely depleted, with values lower than 1 $\mu \mathrm{M}$ from the surface to about 40-50 m depth. However, the position of the nitracline differs between the two transects. For the northern transect, it was as deep as 48 $\mathrm{m}$ at the most oceanic station and shoaled coastwards, being $23 \mathrm{~m}$ deep at station F4 (Fig. 4). In contrast, for the southern transect the nitracline deepened coastward following the $18^{\circ} \mathrm{C}$ isotherm (Fig. 5). The phosphate distribution of the southern transect was similar to the nitrate distribution, with values lower than $0.1 \mu \mathrm{M}$ from the surface to about $45 \mathrm{~m}$ depth. However, the northern transect also showed higher values for the upper $40 \mathrm{~m}$, with the maximum phosphate levels close to the River Guadalquivir ( $>0.15 \mu \mathrm{M})$ (Fig. 4). Silicate distributions followed the same trend as nitrate ones, except at the coastal stations, where levels $>1 \mu \mathrm{M}$ were recorded (Figs. 4 and 5). In transect F, the chl $a$ distribution showed low values ( $\mathrm{chl} a<0.5 \mathrm{mg} \mathrm{m}^{-3}$ ) in shallow waters except close to the Guadalquivir River (Fig. 4). At the offshore stations, the chl $a$ maximum was observed at the depth of the nitracline, while it was located close to the bottom at the inshore stations, with 

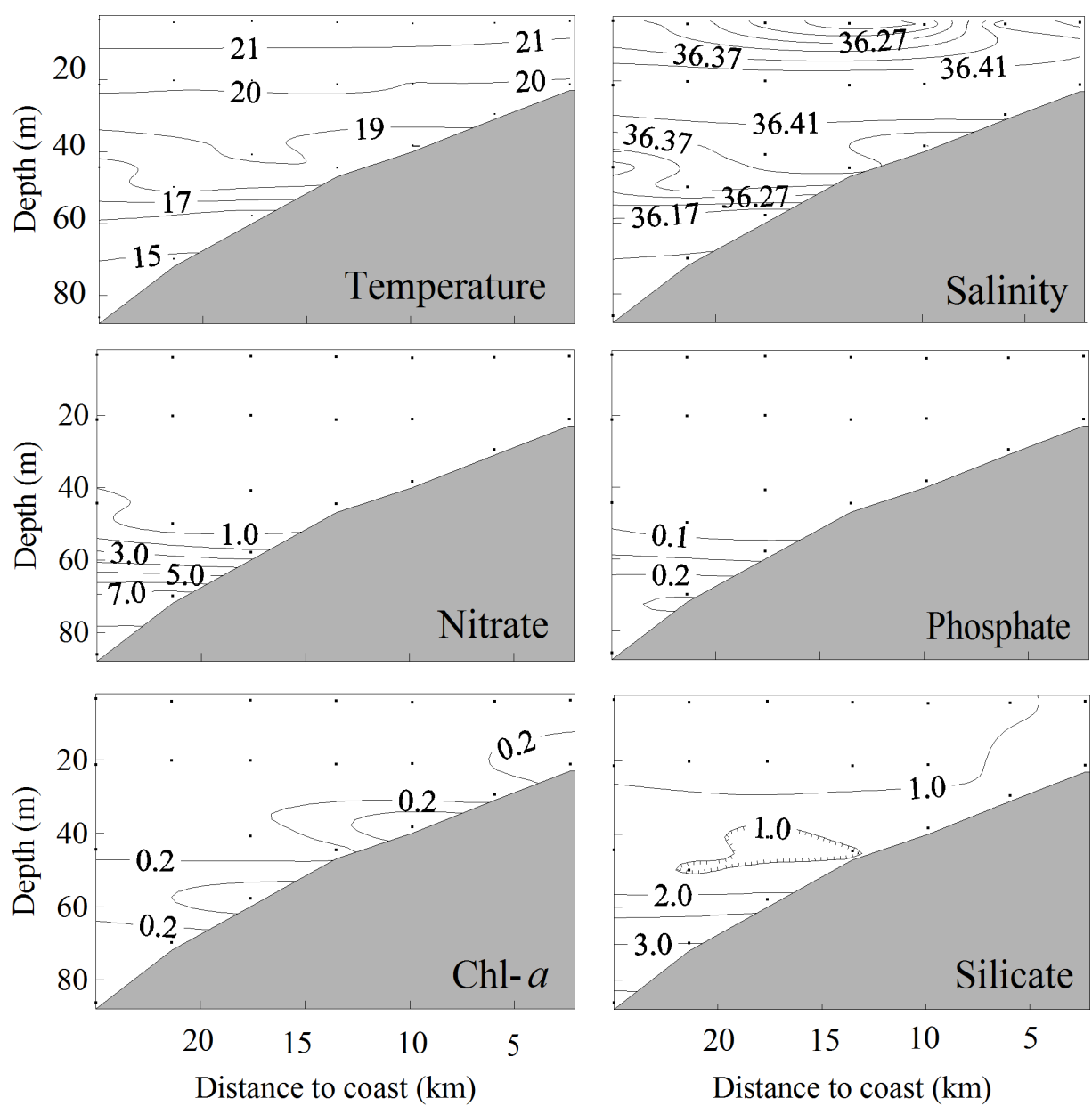

FIG. 5. - Vertical distribution of temperature, salinity, nitrate, phosphate, chl $a$ and silicate at transect B in the Gulf of Cádiz in June 2006. T in ${ }^{\circ} \mathrm{C}$, chl $a$ in $\mathrm{mg} \mathrm{m}^{-3}$, and nutrients in $\mu \mathrm{M}$.

values as high as $2.6 \mathrm{mg} \mathrm{m}^{-3}$. The chl $a$ distribution for the southern transect B was similar to the northern distribution but with lower values, showing a subsurface chl $a$ maximum. The greatest difference was the low surface values for the entire transect $\left(<0.1 \mathrm{mg} \mathrm{m}^{-3}\right.$; Fig. 4 and 5).

\section{Thermohaline and chemical characterization of water masses}

Based on the previous results and applying a TS diagram, four different water types in the study area were differentiated (Fig. 6a). The cluster of points following a linear TS relationship corresponds to North Atlantic Central Water (NACW), with temperatures of $14-18^{\circ} \mathrm{C}$ and salinity of 36.0-36.3. Between this water mass and the salinity maximum, the water samples corresponded to Surface Atlantic Water (SAW) as described by Navarro et al. (2006). According to these authors SAW is considered as a modification of NACW due to stratification and air-sea interactions. SAW had a temperature of $18-22^{\circ} \mathrm{C}$ and a salinity of $36.3-36.5$. Taking into account the north-south zonation described in the previous section, we discerned two different surface waters (SW): South Surface Waters with a temperature of $17-22^{\circ} \mathrm{C}$ and a salinity of $\sim 36.4$, and North Surface Waters with higher temperature $\left(\Delta \mathrm{T}=20-24^{\circ} \mathrm{C}\right)$ and a salinity of 36.3-36.4.

From a chemical point of view, the nutrient $v s$. temperature relationships (Fig. 6b, c and d) show that colder waters are characterized by high nutrient levels, while warmer waters are characterized by low nutrient levels. The NACW was characterized by high nutrient

TABLE 1. - Linear regression between salinity $(\mathrm{S})$, temperature $(\mathrm{T})$, nitrate $(\mathrm{N})$, phosphate $(\mathrm{P})$ and silicate $(\mathrm{Si}) . \mathrm{T}$ in ${ }^{\circ} \mathrm{C}$ and nutrients in $\mu \mathrm{M}$. Only significant relationships are included.

\begin{tabular}{|c|c|c|c|}
\hline & Linear regression & $r^{2}$ & $\mathrm{n}$ \\
\hline \multicolumn{4}{|l|}{ NACW } \\
\hline $\mathrm{T}=$ & $-451( \pm 32)+12.9( \pm 0.9) \mathrm{S}$ & 0.85 & 37 \\
\hline $\mathrm{N}=$ & $41.7( \pm 3.3)-2.4( \pm 0.2) \mathrm{T}$ & 0.78 & 37 \\
\hline $\mathrm{P}=$ & $1.16( \pm 0.15)-0.06( \pm 0.01) \mathrm{T}$ & 0.51 & 37 \\
\hline $\mathrm{Si}=$ & $16.03( \pm 1.62)-0.82( \pm 0.10) \mathrm{T}$ & 0.64 & 37 \\
\hline $\mathrm{N}=$ & $-1.57( \pm 0.53)+27.9( \pm 2.5) \mathrm{P}$ & 0.76 & 37 \\
\hline $\mathrm{N}=$ & $-3.16( \pm 0.46)+2.43( \pm 0.15) \mathrm{Si}$ & 0.87 & 37 \\
\hline \multicolumn{4}{|l|}{ South SW } \\
\hline $\mathrm{N}=$ & $3.6( \pm 0.7)-0.16( \pm 0.03) \mathrm{T}$ & 0.35 & 45 \\
\hline $\mathrm{Si}=$ & $4.8( \pm 0.7)-0.18( \pm 0.04) \mathrm{T}$ & 0.37 & 47 \\
\hline $\mathrm{N}=$ & $-0.43( \pm 0.09)+0.7( \pm 0.1) \mathrm{Si}$ & 0.55 & 45 \\
\hline
\end{tabular}



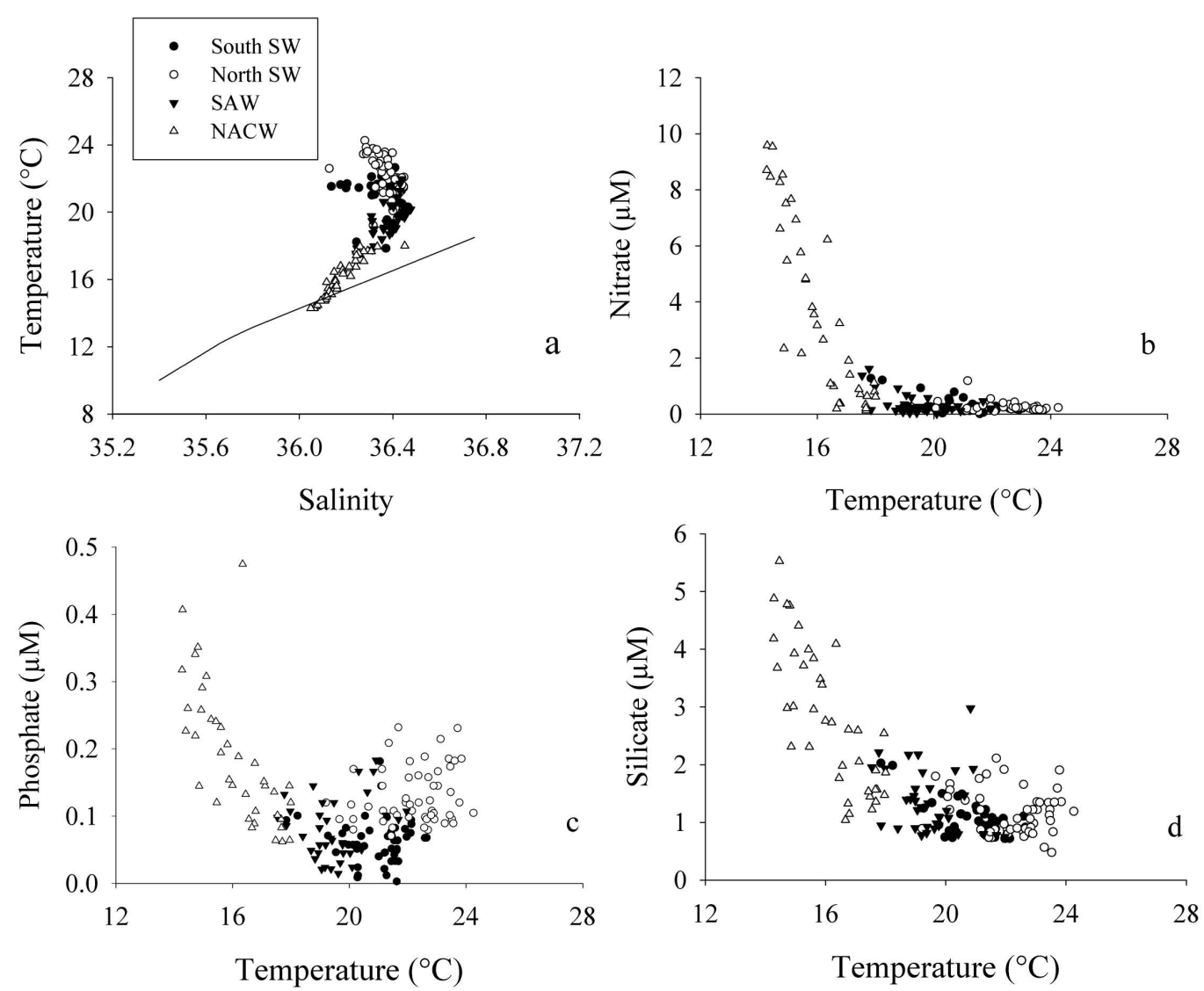

FIG. 6. - Temperature-Salinity diagram (a) and relationship between temperature and nitrate (b), phosphate (c) and silicate (d) for all the collected samples during the Emigas I survey. NACW, SAW, South SW, North SW are the acronyms for North Atlantic Central Water, Surface Atlantic Water, North Surface Water and South Surface Water, respectively. NACW-TS refers line from Fiuza (1984).

levels, with values between 0.06 and $9.6 \mu \mathrm{M}$ for $\mathrm{NO}_{3}$, 0.12 and $0.5 \mu \mathrm{M}$ for $\mathrm{PO}_{4}$ and 1 and $5.5 \mu \mathrm{M}$ for $\mathrm{SiO}_{2}$ and with significant correlations between nutrients and temperature $(P<0.05)$. No significant correlations between nutrients and thermohaline properties were found for SAW and North and South Surface Waters except for nitrate and silicate $v s$. temperature for the southern part $(P<0.05)$ (Table 1). Significant nutrient relationships for NACW were observed, such as those between silicate and phosphate vs. nitrate (Table 1). Phosphate and silicate concentrations for surface and SAW were significantly different except for silicate concentrations of SAW and northern surface waters. For the shallow waters, nitrate and phosphate levels were almost zero but silicate concentrations were $>1 \mu \mathrm{M}$ (Table 2).

TABLE 2. - Average values of temperature (T), salinity (S), nitrate $(\mathrm{N})$, phosphate $(\mathrm{P})$ and silicate $(\mathrm{Si})$ for NACW, SAW and North and South SW. T in ${ }^{\circ} \mathrm{C}$ and nutrients in $\mu \mathrm{M}$.

\begin{tabular}{lccccc}
\hline & $\mathrm{T}$ & $\mathrm{S}$ & $\mathrm{N}$ & $\mathrm{P}$ & $\mathrm{Si}$ \\
\hline North SW & $22.3 \pm 1.1$ & $36.36 \pm 0.06$ & $0.23 \pm 0.17$ & $0.13 \pm 0.04$ & $1.16 \pm 0.38$ \\
South SW & $21 \pm 1$ & $36.37 \pm 0.08$ & $0.27 \pm 0.27$ & $0.06 \pm 0.03$ & $1.02 \pm 0.30$ \\
SAW & $19.6 \pm 1.2$ & $36.37 \pm 0.07$ & $0.33 \pm 0.36$ & $0.08 \pm 0.05$ & $1.37 \pm 0.53$ \\
NACW & $16.2 \pm 1.2$ & $36.18 \pm 0.09$ & $3.62 \pm 3.20$ & $0.19 \pm 0.10$ & $2.78 \pm 1.23$ \\
\hline
\end{tabular}

\section{DISCUSSION}

\section{Thermohaline characterization of water masses in the Gulf of Cádiz}

Based on the thermohaline properties, four different water masses were discerned for the continental shelf of the Gulf of Cádiz in summer 2006: NACW, SAW and North and South Surface Waters. Strictly speaking, the last three can not be defined as water masses though we use this terminology for practical purposes. With some differences, the characterization is similar to that reported by Criado-Aldeanueva et al. (2006a) and Navarro et al. (2006), who state that central waters in the Gulf of Cádiz can be divided into pure NACW and modified central water, coined as SAW. On our cruise, the NACW samples showed a linear TS relationship (Fig. 6a), whereas SAW samples diverged from this linear relationship probably due to air-sea interactions (Criado-Aldeanueva et al., 2006a). SAW showed a higher temperature (between 21 and $24^{\circ} \mathrm{C}$, typical of the summer season for the area [Peliz et al., 2007; Sanchez-Lamadrid et al., 2003]) and salinity than NACW, with a salinity maximum of 36.5. The isopycnal level of $26.66 \mathrm{~kg} \mathrm{~m}^{-3}$ was 
proposed as the limit between NACW and SAW by Navarro et al. (2006), who observed the winter mixed layer in the Gulf of Cádiz to have a density anomaly of $26.66 \mathrm{~kg} \mathrm{~m}^{-3}$ and high nutrient levels. As the seasonal stratification proceeds, the winter mixed layer nutrient concentrations were consumed due to phytoplankton activity, so during the summer period the water volume had salinities of NACW but higher temperatures and very low nutrient levels. These authors defined this water volume as SAW and established its lower isopycnal level at $26.66 \mathrm{~kg} \mathrm{~m}^{-3}$. We also established the limit between SAW and NACW at the nitracline depth (as explained in the next section) but in our case this limit was established at a shallower isopycnal level: $26.3 \mathrm{~kg} \mathrm{~m}^{-3}$.

Fiuza (1984) studied the central waters between $35^{\circ} \mathrm{N}$ and $42^{\circ} \mathrm{N}$ and east of the Mid-Atlantic ridge. He differentiated between ENACW (Eastern North Atlantic Central Water) of subtropical origin $\left(\mathrm{ENACW}_{\mathrm{T}}\right)$, with $\mathrm{T}>12^{\circ} \mathrm{C}$ and $\mathrm{S}<35.70$ and formed south of $43^{\circ} \mathrm{N}$; and ENACW of subpolar origin formed north of $43^{\circ} \mathrm{N}$ and with colder temperatures $\left(<10^{\circ} \mathrm{C}\right)$ and $\mathrm{S}>35.70$. If we compare our data with this reference TS relationship, NACW found in the Gulf of Cádiz in June 2006 corresponded to ENACW of subtropical origin, though slightly modified. We found NACW with a slope of 12.2, which is higher than the T/S slope of 7.06 of Criado-Aldeanueva et al. (2006a) .

These two TS relationships had a higher slope than Fiuza's TS, based on the climatology for the Central Waters, so they may have shown a seasonal warming. We distinguished two types of surface waters because our study region is closer to shore and consequently more affected by continental inputs: North and South Surface Waters. This differentiation was corroborated by the TS diagram, since the northern water was less salty and warmer than the southern one, due to the influence of the River Guadalquivir.

\section{Chemical characterization of water masses in the Gulf of Cádiz}

The shallow waters in the Gulf of Cádiz during Emigas I in June 2006 were almost depleted in nitrate $(<0.2 \mu \mathrm{M})$ and phosphate $(<0.1 \mu \mathrm{M})$ except for the stations close to the River Guadalquivir. Similar situations were described for the summer period by García et al. (2002) and Ruiz et al. (2006). These authors found undetectable concentrations of nitrate in the upper water of the basin but with high levels in the River Guadalquivir region. Based on other studies (Ruiz et al., 2006; Huertas et al. 2006) and our own research, the system-except for the River Guadalquivir-seems to evolve from a situation of high nutrient conditions in winter to oligotrophic conditions in summer due to prolonged phytoplankton activity triggered by the spring phytoplankton bloom. At deeper levels, only Navarro et al. (2006) analyzed the nutrient distributions



FIG. 7. - Temperature-Salinity diagram with nitrate concentration for all stations during the Emigas I survey.

at the depth horizons of 75,100 and $200 \mathrm{~m}$. Our nitrate levels were similar to those reported by these authors, but their silicate values, ranging between 0.5 and -1.0 $\mu \mathrm{M}$, were lower than our results at the same depths (silicate levels between 1.4 and $5.5 \mu \mathrm{M}$ ). It is evident that high levels of nutrients are associated with deep waters with low temperature and salinity, corresponding to NACW. This high correlation between nutrients and the thermohaline properties for NACW is clearly shown with the nitrate-categorized TS diagram (Fig. 7). The NACW samples showed higher nitrate concentrations $(>1 \mu \mathrm{M}$ ), while the shallower waters (SAW and southern and northern surface waters) showed lower concentrations. Thus, based on this diagram, we establish the limit between nutrient-rich NACW and nutrient-poor water at the isopycnal level of $26.3 \mathrm{~kg} \mathrm{~m}^{-3}$. It is important to note that our limit is shallower than the isopycnal level of $26.66 \mathrm{~kg} \mathrm{~m}^{-3}$ found by Navarro et al. (2006) in May 2001, as mentioned above. The Emigas I survey was carried out later in the year, so we should expect surface waters in June to have suffered stronger nutrient consumption since the spring phytoplankton bloom and the nitracline should therefore be deeper in the water column. However, the situation was just the opposite, with a shallower isopycnal level for June 2006. We suggest that this differentiation was due to different interannual winter conditions and important seasonal variability (Garcia-Lafuente et al., 2006), which could induce noticeable changes in the surface circulation according with Machin et al. (2006).

Only for NACW a significant correlation between nutrients was found $\left(r^{2}>0.75\right)(P<0.05)$. The nitratephosphate ratio $(27.9 \pm 2.5)$ was higher than the Redfield ratio (Redfield et al. 1963). A high N:P ratio was also found by other authors for ENACW. During 


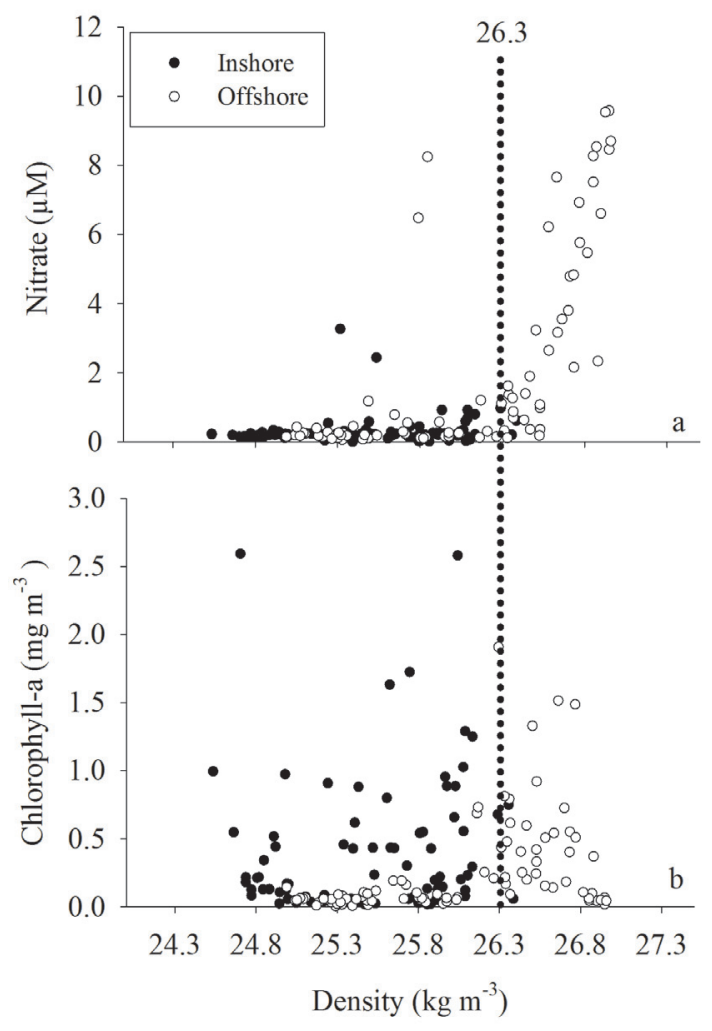

FIG. 8. - Relationship between nitrate (a), chl $a$ (b) and density in the Gulf of Cádiz during the Emigas I survey.

the Galicia VII cruise in the region east of $12^{\circ} \mathrm{W}$ and between 43 and $47^{\circ} \mathrm{N}$, Fraga et al. (1985) reported an $\mathrm{N}: \mathrm{P}$ ratio of 21 for the ENACW of subtropical and subpolar origin. $\mathrm{N}_{2}$ fixation was invoked by Fanning (1987, 1992) to explain high N:P ratios in the thermocline waters of the western North Atlantic subtropical gyre. The nitrate-silicate ratio observed for NACW was $2.4 \pm 0.15$. This ratio was almost the same as that determined by several authors in North Atlantic central waters (Treguer and Le Corre, 1979; Minas et al., 1991; Castro et al., 2006), suggesting a low incorporation of silicon relative to nitrogen.

In the River Guadalquivir we found an average $\mathrm{N}: \mathrm{P}$ ratio of $37 \pm 4$, which is higher than the Redfield ratio, indicating that the River Guadalquivir is P-limited, like most continental aquatic ecosystems (Turner et al., 2003).

\section{Coupling between the chemical and biological fields}

The distribution of chl $a$ in the Gulf of Cádiz in June 2006 was similar to that of previous studies of the region (Huertas et al., 2005; Ruiz et al., 2006; Navarro et al., 2006; Huertas et al., 2006; Garcia et al., 2002), with a surface maximum close to the River Guadalqui$\operatorname{vir}\left(>2 \mathrm{mg} \mathrm{m}^{-3}\right)$ and a subsurface maximum for the rest of the area. At the offshore stations, the subsurface chl $a$ maximum was located at the depth of the nitracline and associated with the $26.3 \mathrm{~kg} \mathrm{~m}^{-3}$ isopycnal level rather than with the pycnocline depth, as shown in Figure 8 . In fact, a high correlation between nitracline depth and the chl $a$ maximum depth for these stations ( $r$ $>0.87$ ) was obtained. Navarro et al. (2006) also found a strong correlation between the $26.66 \mathrm{~kg} \mathrm{~m}^{-3}$ isopycnal depth and the deep fluorescence maximum through the whole Gulf of Cádiz in May 2001. However, the situation changed completely for the inshore stations, where nitrate levels were lower than $1 \mu \mathrm{M}$ for the entire water column and chl $a$ maxima were observed at the bottom except at the River Guadalquivir stations. The chl $a$ levels at the bottom depth were always higher than $0.1 \mathrm{mg} \mathrm{m}^{-3}$, with a band of maximum values $(>0.6$ $\mathrm{mg} \mathrm{m}^{-3}$ ) located approximately in the middle of each transect. These deep chl $a$ maxima were not limited by light, as the photosynthetically available radiation was higher than $1 \%$ even at the bottom. We assumed that at these inshore stations the nutrient supply is due to efflux from the sediment based on the results by Ferrón et al. (2009), who measured positive nitrogen and phosphorous fluxes from the sediment to the water column at a series of stations off the Guadalquivir close to our stations (F3, F7 and G6, G3) and the Bay of Cádiz region during the same period of June 2006.

\section{CONCLUSIONS}

A strong vertical stratification typical of the summer season was observed in the Gulf of Cádiz in June 2006. The shallow waters close to the coast showed high salinity except close to the River Guadalquivir. We differentiated four different types of water based on the thermohaline properties: North Atlantic Central Water (NACW), Surface Atlantic Water (SAW), and South Surface and North Surface waters (SW). The highest concentrations of nutrients were associated with NACW. In fact, at shallow waters low levels of nutrients were detected, except in the River Guadalquivir region. The limit between NACW and SAW was established at the isopycnal level of 26.3 $\mathrm{kg} \mathrm{m}^{-3}$. The high nitrate-phosphate ratio $(27.9 \pm 2.5)$ suggests that phosphate is probably the limiting factor of primary production in this area during the summer period. Chl $a$ distribution showed a surface maximum close to the River Guadalquivir and a subsurface maximum in the rest of the area. At the offshore stations, the subsurface chl $a$ maximum was located at the depth of the nitracline and associated with the $26.3 \mathrm{~kg} \mathrm{~m}^{-3}$ isopycnal level. At the inshore stations chl $a$ maxima were observed at the bottom except at the River Guadalquivir stations.

\section{ACKNOWLEDGEMENTS}

The authors would like to thank the crew of the $R / V$ Mytilus for their valuable assistance during the cruises and the Instituto de Investigaciones Marinas (CSIC) of 
Vigo for the human and technical support. This work was supported by the Spanish CICYT (Spanish Commission for Research and Development) under contract CTM2005-01364/MAR. E.A. was funded by a grant from the Spanish MECD, we also thank the research project from the Junta de Andalucia PO7-RNM01397.

\section{REFERENCES}

Castro, C.G., M. Nieto-Cid, X.A. Alvarez-Salgado and F.F. Perez. -2006 . Local remineralization patterns in the mesopelagic zone of the Eastern North Atlantic, off the NW Iberian Peninsula. Deep-Sea Res. I, 53: 1925-1940.

Criado-Aldeanueva, F., J. Garcia-Lafuente, J.M. Vargas, J. Del Rio, A. Vazquez, A. Reul and A. Sanchez. - 2006a. Distribution and circulation of water masses in the Gulf of Cádiz from in situ observations. Deep-Sea Res. II, 53: 1261-1281.

Criado-Aldeanueva, F., J. García-Lafuente, J.M. Vargas, J. Del Rio, A. Sanchez, J. Delgado and J.C. Sanchez. - 2006b. Wind induced variability of hydrographic features and water masses distribution in the Gulf of Cádiz (SW Iberia) from in situ data. J. Mar. Syst., 63(3-4): 130-140.

Fanning, K. - 1987. Anomalous $\mathrm{NO}_{3} / \mathrm{PO}_{4}$ ratios in the west central North Atlantic Ocean (abstract). Eos Transaction AGU, 68: 1754.

Fanning, K. - 1992. Nutrients provinces in the sea: concentration ratios, reaction rate ratios, and ideal covariation. J. Geophys. Res., 97: 5693-5712.

Ferrón, S., F. Alonso-Pérez, E. Anfuso, F.J. Murillo, T. Ortega, C.G. Castro and J.M. Forja. - 2009. Benthic nutrient recycling in the northeastern shelf of the Gulf of Cádiz (SW Iberian Peninsula). Mar. Ecol. Prog. Ser., 390: 79-95.

Fiuza, A.F.G., M.E. de Macedo and M.R. Guerreiro. - 1982. Climatological space and time variations of the Portuguese coastal upwelling. Oceanol. Acta, 5: 31-40.

Fiuza, A.F.G. - 1983. Upwelling Patterns off Portugal. In: E. Suess and J. Thiede (eds.), Coastal Upwelling, pp. 85-89. Plenum, New York.

Fiuza, A.F.G. - 1984. Hidrologia e dinamica das aguas costeiras de Portugal. Ph.D. thesis, Univ. Lisboa.

Folkard, A.M., P.A. Davies, A.F.G. Fiuza and I. Ambar. - 1997. Remotely sensed sea surface thermal patterns in the Gulf of Cádiz and Strait of Gibraltar: variability, correlations and relationships with the surface wind field. J. Geophys. Res., 102: 5669-5683.

Fraga, F., E.D. Barton and O. Llinas. - 1985. The concentration of nutrients salts in 'pure' North and South Atlantic Central Waters. In: Simposio Internacional sobre las Areas de Afloramiento mas importantes del Oeste Africano 1: 51-77. Instituto de Investigaciones Pesqueras, Barcelona.

Garcia, C.M., L. Prieto, M. Vargas, F. Echevarria, J. Garcia-Lafuente, J. Ruiz and J.P. Rubin. - 2002. Hydrodynamics and the spatial distribution of plankton and TEP in the Gulf of Cádiz (SW Iberian Peninsula). J. Plankton Res., 24(8): 817-833.

Garcia-Lafuente, J., J. Delgado, F. Criado-Aldeanueva, M. Bruno and J.M. Vargas. - 2006. Water mass circulation on the continental shelf of the Gulf of Cádiz. Deep-Sea Res. II, $53: 1261-1281$

Garcia-Lafuente, J. and J. Ruiz. - 2007. The Gulf of Cádiz pelagic ecosystem: A review. Prog. Oceanogr., 74: 228-251.

Gascard, J.C. and C. Richez. - 1985. Water masses and circulation in the Western Alboran Sea and in the Strait of Gibraltar. Prog. Oceanogr., 15: 157-216.

Gattuso, J.P., M. Frankignoulle and R. Wollast. - 1998. Carbon and carbonate metabolism in coastal aquatic ecosystems. Annu. Rev. Ecol. Syst., 29: 405-434.

Grasshoff, K., M. Ehrhardt and Kremling, K. - 1983. Methods of seawater analysis, 2nd, rev. and extended ed. Verlag-Chemie, Weinheim.

Huertas, I.E., G. Navarro, S. Rodriguez-Galvez and L. Prieto. 2005. The influence of phytoplankton biomass on the spatial distribution of carbone dioxide in surface sea water of a coastal area of the Gulf of Cádiz (southwestern Spain). Can. J. Bot., 83: 929-940.
Huertas, I.E., G. Navarro, S. Rodriguez-Galvez and L.M. Lubian. 2006. Temporal patterns of carbon dioxide in relation to hydrological conditions and primary production in the northeastern shelf of the Gulf of Cádiz (SW Iberian Peninsula). Deep-Sea Res. II, 53: 1344-1362.

Machín, F., J.L. Pelegrí, A. Marrero-Diaz, I. Laiz and A.W. Ratsimandresy. - 2006. Near-surface circulation in the southern Gulf of Cádiz. Deep-Sea Res. II, 53(11-13): 1161-1181.

Minas, H.J., B. Coste, P. Le Corre, M. Minas and P. Raimbault. 1991. Biological and Geochemical Signatures Associated With the Water Circulation Through the Strait of Gibraltar and in the Western Alboran Sea. J. Geophys. Res. 96: 8755-8771.

Moran, X.A.G., I. Taupier-Letage, E. Vazques-Dominguez, S. Ruiz, L. Arin, P. Raimbault and M. Estrada. - 2001. Physicalbiological coupling in the Algerian Basin (SW Mediterranean): influence of mesoscale instabilities on the biomass and production of phytoplankton and bacterioplankton. Deep-Sea Res. I, 48: 405-437.

Navarro, G. and J. Ruiz. - 2006. Spatial and temporal variability of phytoplankton in the Gulf of Cádiz through remote sensing images. Deep-Sea Res. II, 53: 1241-1260.

Navarro, G., J. Ruiz, I.E. Huertas, C.M. Garcia, F. Criado-Aldeanueva and F. Echevarria. - 2006. Basin-scale structure governing the position of the deep fluorescence maximum in the Gulf of Cádiz. Deep-Sea Res. II, 53: 1182-1197.

Peliz, Á., J. Dubert, P. Marchesiello and A. Teles-Machado. - 2007. Surface circulation in the Gulf of Cádiz: Model and mean flow structure. J. Geophys. Res., 112: C11015.

Prieto, L., C.M. Garcia, A. Corzo, J. Ruiz Segura and F. Echevarria. - 1999. Phytoplankton, bacerioplankton and nitrate reductase activity distribution in relation to physical structure in the northern Alboran Sea and Gulf of Cádiz (southern Iberian Peninsula). Bol. Inst. Esp. Oceanogr., 15(1-4): 401-411.

Redfield, A.C., B.H. Ketchum and F.A. Richards. -1963 . The influence of organism on the composition of sea water. In: M.N. Hill (eds.), The Sea, 2: 26-77. Wiley-Interscience, New York.

Revals, P. and E.D. Barton. - 2002. Mesoscale patterns in the Cape Sao Vicente (Iberian Peninsula) upwelling region. J. Geophys. Res., 107: 3164-3186.

Ruiz, J., E. Garcia-Isarch, I.E. Huertas, L. Prieto, A. Juarez, J.L. Muóz, A. Sanchez-Lamadrid, S. Rodriguez-Galvez, J.M. Naranjo and F. Baldó. - 2006. Meteorological and oceanographic factors influencing Engraulius encrasicolus early life stages and catches in the Gulf of Cádiz. Deep-Sea Res. II, 53: 1261-1281.

Sanchez, R. and P. Revals. - 2003. Spring-Summer climatological circulation in the upper layer in the region of Cape St. Vincent, Southwest Portugal. ICES J. Mar. Sc., 60: 1232-1250.

Sanchez-Lamadrid, A., J. Ruiz, E. Garcia, A. Juarez, T. Jimenez, I. Sobrino, E. Blanco, P. Jimenez, M. Bruno and G. Navarro. - 2003. Estudio de los recursos pesqueros del Golfo de Cádiz. Consejeria de Agricultura y Pesca, Junta de Andalucia.

Stevenson, R.E. - 1977. Huelva Front and Malaga, Spain, Eddy Chain as defined by Satellite and Oceanographic Data. Dtsch. Hydrogr. Z., 30: 51-53.

Treguer, P. and P. Le Corre. - 1979. The ratios of nitrate, phosphate, and silicate during uptake and regeneration phases of the Moroccan upwelling regime. Deep-Sea Res. I, 26: 163-184.

Turner, R.E., N.N. Rabalais, D. Justic and Q. Dortch. - 2003. Global patterns of dissolved N, P and Si in large rivers. Biogeochem., 64: 297-317.

Wollast, R. - 1993. Interactions of carbon and nitrogen cycles in the coastal zone. In: R. Wollast, F.T. Mackenzie and L. Chou (eds.), Interactions of $C, N, P$ and $S$ biogeochemical cycle and global change, 4: 195-210. Springer, Berlin.

Wollast, R. - 1998. Evaluation and comparison of the global carbon cycle in the coastal zone and in the open ocean. In: K.H. Brink and Robinson, A.R. (eds.), The Sea, 213-252. Willey and Sons, New York.

Wollast, R. - 2002. Continental moooargins - review of geochemical settings. In: Wefer G, Billet D, Hebbeln D, Jørgensen BB, Schlüter M, van Weering TCE (eds.), Ocean margin systems, pp. 15-31. Springer, Berlin.

Received November 1, 2008. Accepted June 1, 2010.

Published online November 13, 2010. 